ҚАЗАҚСТАН РЕСПУБЛИКАСЫ

ҰЛТТЫҚ ҒЫЛЫМ АКАДЕМИЯСЫНЫН

АБАЙ АТЫНДАҒЫ ҚАЗАҚ ҰЛТТЫҚ

ПЕДАГОГИКАЛЫҚ УНИВЕРСИТЕТІНІҢ

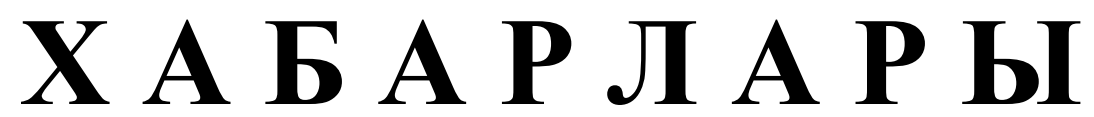

\section{ИЗВЕСТИЯ}

НАЦИОНАЛЬНОЙ АКАДЕМИИ НАУК РЕСПУБЛИКИ КАЗАХСТАН

КАЗАХСКИЙ НАЦИОНАЛЬНЫЙ

ПЕДАГОГИЧЕСКИЙ УНИВЕРСИТЕТ ИМ. АБАЯ

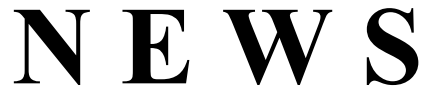

OF THE NATIONAL ACADEMY OF SCIENCES OF THE REPUBLIC OF KAZAKHSTAN

ABAY KAZAKH NATIONAL PEDAGOGICAL UNIVERSITY

ҚОҒАМДЫҚ ЖӘНЕ ГУМАНИТАРЛЫҚ ҒЫЛЫМДАР СЕРИЯСЫ

СЕРИЯ ОБЩЕСТВЕННЫХ И ГУМАНИТАРНЫХ НАУК

$\checkmark$

SERIES OF SOCIAL AND HUMAN SCIENCES

$$
5 \text { (321) }
$$

КЫРКУЙЕК - КАЗАН 2018 ж.

СЕНТЯБРЬ - ОКТЯБРЬ 2018 Г.

SEPTEMBER - OCTOBER 2018

1962 ЖЫЛДЫҢ ҚАНТАР АЙЫНАН ШЫҒА БАСТАҒАН

ИЗДАЕТСЯ С ЯНВАРЯ 1962 ГОДА

PUBLISHED SINCE JANUARY 1962

ЖЫЛЫНА 6 РЕТ ШЫҒАДЫ

ВЫХОДИТ 6 РАЗ В ГОД

PUBLISHED 6 TIMES A YEAR 
Ба с ре дактор

ҚР ҰҒА кұрметті мүшесі

Балықбаев Т.O.

Р е д а ц и я а лқ а сы:

экон. ғ. докторы, проф., ҚР ҰҒА академигі Баймұратов У.Б.; тарих ғ. докторы, проф., ҚР ҰҒА академигі Байпақов К.М.; филос. ғ.докторы, проф., ҚР ҰҒА академигі Есім Г.Е.; фил. ғ. докторы,, проф., ҚР ҰҒА академигі Қирабаев С.С.; эк. ғ. докторы, проф., ҚР ҰҒА академигі Кошанов А.К.; эк.ғ. докторы, проф., ҚР ҰҒА академигі Нәрібаев К.Н. (бас редактордың орынбасары); филос. ғ.докторы, проф., ҚР ҰҒА академигі Нысанбаев А.Н.; заң ғ. докторы, проф., ҚР ҰҒА академигі Сәбікенов С.Н.; заң ғ. докторы, проф., ҚР ҰҒА академигі Сүлейменов М.К.; эк. ғ. докторы, проф., ҚР ҰҒА академигі Сатыбалдин С.С.; тарих ғ. докторы, проф., ҚР ҰҒА академик Әбжанов Х.М.; тарих ғ. докторы, проф., ҚР ҰҒА корр. мүшесі Әбусеитова М.Х.; тарих ғ. докторы, проф., ҚР ҰҒА академик Байтанаев Б.А.; филол. ғ. докторы, проф., ҚР ҰҒА корр. мүшесі Жақып Б.А.; фил. ғ. докторы, проф., академик НАН РК Қалижанов У.К.; филол. ғ. докторы, проф., ҚР ҰҒА академик Қамзабекұлы Д.; тарих ғ. докторы, проф., ҚР ҰҒА академик Қожамжарова Д.П.; тарих ғ. докторы, проф., ҚР ҰҒА академик Койгелдиев М.К.; фил. ғ. докторы, проф., ҚР ҰҒА корр. мүшесі Кұрманбайұлы Ш.; тарих ғ. докторы, проф., ҚР ҰҒА корр. мүшесі Таймағанбетов Ж.К.; социол. ғ. докторы, проф., ҚР ҰҒА корр. мүшесі Шәукенова 3.К.; фил. ғ. докторы, проф., КР ҰҒА корр. мүшесі Дербісәлі А.; саяси. ғ. докторы, проф., Бижанов А.К., тарих ғ. докторы, проф., Кабульдинов 3.Е.; фил. ғ. докторы, проф., ҚР ҰҒА корр мүшесі Қажыбек Е.3.

\section{Р едакция ке н е с i:}

Молдова Республикасының ҰҒА академигі Белостечник Г. (Молдова); Әзірбайжан ҰҒА академигі Велиханлы Н. (Азербайджан); Тәжікстан ҰҒА академигі Назаров Т.Н. (Тәжікстан); Молдова Республикасының ҰҒА академигі Рошка А. (Молдова); Молдова Республикасының ҰҒА академигі Руснак Г. (Молдова); Әзірбайжан ҰҒА корр. мүшесі Мурадов Ш. (Әзірбайжан); Әзірбайжан ҰҒА корр. мүшесі Сафарова 3. (Әзірбайжан); э. ғ. д., проф. Василенко В.Н. (Украина); заң ғ. докт., проф. Устименко В.А. (Украина)

«Қазақстан Республикасы Ұлттық ғылым академиясының Хабарлары. Қоғамдық және гуманитарлық ғылымдар сериясы». ISSN 2224-5294

Меншіктенуші: «Қазақстан Республикасының Ұлттық ғылым академиясы» РҚБ (Алматы қ.)

Қазақстан республикасының Мәдениет пен ақпарат министрлігінің Ақпарат және мұрағат комитетінде 30.04.2010 ж. берілген № 10894-Ж мерзімдік басылым тіркеуіне қойылу туралы куәлік

Мерзімділігі: жылына 6 рет.

Тиражы: 500 дана.

Редакцияның мекенжайы: 050010, Алматы қ., Шевченко көш., 28, 219 бөл., 220, тел.: 272-13-19, 272-13-18, http://nauka-nanrk.kz. social-human.kz

(C) Қазақстан Республикасының Ұлттық ғылым академиясы, 2018

Типографияның мекенжайы: «Аруна» ЖК, Алматы қ., Муратбаева көш., 75. 
Главный редакто $p$

Почетный член НАН РК

T.O. Балыкбаев

Р е дак ци онн а я коллег и я:

докт. экон. Н., проф., академик НАН РК У.Б. Баймуратов; докт. ист. н., проф., академик НАН РК К.М. Байпаков; докт. филос. Н., проф., академик НАН РК Г.Е. Есим; докт. фил. Н., проф., академик НАН РК С.С. Кирабаев; докт. экон. Н., проф., академик НАН РК А.К. Кошанов; докт. экон. Н., проф., академик НАН РК К.Н. Нарибаев (заместитель главного редактора); докт. филос. н., проф., академик НАН РК А.Н. Нысанбаев; докт. юр. Н., проф., академик НАН РК С.Н. Сабикенов; докт. юр. н., проф., академик НАН РК М.К. Сулейменов; докт. экон. Н., проф., академик НАН РК С.С. Сатубалдин; докт. ист. н., проф., академик НАН РК Х.М. Абжанов; докт. ист. н., проф., чл.-корр. НАН РК М.Х. Абусеитова; докт. ист. н., проф., академик НАН РК Б.А. Байтанаев; докт. фил. н., проф., чл.-корр. НАН РК Б.А. Жакып; докт. фиолол. н., проф., академик НАН РК У.К. Калижанов; докт. фил. н., проф., академик НАН РК Д. Камзабекулы; докт. ист. н., проф., академик НАН РК Д.П. Кожамжарова; докт. ист. н., проф., академик НАН РК М.К. Койгельдиев; докт. филол. н., проф., чл.-корр. НАН РК Ш. Курманбайулы; докт. ист. н., проф., чл.корр. НАН РК Ж.К. Таймаганбетов; докт. социол. н., проф., чл.-корр. НАН РК З.К. Шаукенова; д. филол. н., проф., чл.-корр. НАН РК А. Дербисали; доктор политических наук, проф., Бижанов А.К.; доктор ист. наук, проф., Кабульдинов 3.Е.; доктор филол. н., проф., член-корр. НАН РК Қажыбек Е.3.

Р е дак ци онны й с ов е т

академик НАН Республики Молдова Г. Белостечник (Молдова); академик НАН Азербайджанской Республики Н. Велиханлы (Азербайджан); академик НАН Республики Таджикистан Т.Н. Назаров (Таджикистан); академик НАН Республики Молдова А. Рошка (Молдова); академик НАН Республики Молдова Г. Руснак (Молдова); чл.-корр. НАН Азербайджанской Республики Ш. Мурадов (Азербайджан), член-корр. НАН Азербайджанской Республики 3.Сафарова (Азербайджан); д. э. н., проф. В.Н. Василенко (Украина); д.ю.н., проф. В.А. Устименко (Украина)

Известия Национальной академии наук Республики Казахстан. Серия общественных и гуманитарных наук. ISSN 2224-5294

Собственник: РОО «Национальная академия наук Республики Казахстан» (г. Алматы)

Свидетельство о постановке на учет периодического печатного издания в Комитете информации и архивов

Министерства культуры и информации Республики Казахстан № 10894-Ж, выданное 30.04.2010 г.

Периодичность 6 раз в год

Тираж: 500 экземпляров

Адрес редакции: 050010, г. Алматы, ул. Шевченко, 28, ком. 219, 220, тел. 272-13-19, 272-13-18, www:nauka-nanrk.kz / social-human.kz

(C) Национальная академия наук Республики Казахстан, 2018 г.

Адрес типографии: ИП «Аруна», г. Алматы, ул. Муратбаева, 75

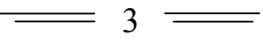


Chief Editor

\section{Honorary member of NAS RK \\ Balykbayev T.O}

Editorial board:

Doctor of economics, prof, academician of NAS RK Baimuratov U.B.; doctor of history, prof, academician of NAS RK Baipakov K.M.; doctor of philosophy, prof, academician of NAS RK Esim G.E.; doctor of philology, prof, academician of NAS RK Kirabayev S.S.; doctor of economics, prof, academician of NAS RK Koshanov A.K.; doctor of economics, prof, academician of NAS RK Naribayev K.N. (deputy editor-in-chief); doctor of philosophy, prof, academician of NAS RK Nyssanbayev A.N.; doctor of law, prof, academician of NAS RK Sabikenov S.N.; doctor of law, prof, academician of NAS RK Suleymenov M.K.; doctor of economy, prof, academician of NAS RK Satybaldin S.S.; doctor of history, prof, academician of NAS RK Abzhanov H.M; doctor of history, prof, corresponding member of NAS RK Abuseitova M.H.; doctor of history, prof, academician of NAS RK Baitanaev B.A.; doctor of philology, prof, corresponding member of NAS RK Zhakyp B.A.; doctor of philology, prof, academician of NAS RK Kalizhanov U.K.; doctor of philology, prof, academician of NAS RK Hamzabekuly D.; doctor of history, prof, academician of NAS RK Kozhamzharova D.P.; doctor of history, prof, academician of NAS RK Koigeldiev M.K.; doctor of philology, prof, corresponding member of NAS RK Kurmanbaiuly Sh.; doctor of history, prof, academician of NAS RK Taimaganbetov J.K.; doctor of sociology, prof, corresponding member of NAS RK Shaukenova Z.K.; doctor of philology, prof, corresponding member of NAS RK Derbisali A.; doctor of political science, prof Bizhanov A.K; doctor of History, prof Kabuldinov Z.E.; doctor of philology, prof, corresponding member of NAS RK Kazhybek E.Z.

\section{Editorial staff:}

Academician NAS Republic of Moldova Belostechnik.G (Moldova); Academician NAS Republic of Azerbaijan Velikhanli N. (Azerbaijan); Academician NAS Republic of Tajikistan Nazarov T.N. (Tajikistan); Academician NAS Republic of Moldova Roshka A. (Moldova) Academician NAS Republic of Moldova Rusnak G. (Moldova); Corresponding member of the NAS Republic of Azerbaijan Muradov Sh. (Azerbaijan); Corresponding member of the NAS Republic of Azerbaijan Safarova Z. (Azerbaijan); Associate professor of Economics Vasilenko V.N. (Ukraine), Associate professor of Law Ustimenko V.A. (Ukraine)

News of the National Academy of Sciences of the Republic of Kazakhstan. Series of Social and Humanities. ISSN 2224-5294

Owner: RPA "National Academy of Sciences of the Republic of Kazakhstan" (Almaty)

The certificate of registration of a periodic printed publication in the Committee of information and archives of the Ministry of culture and information of the Republic of Kazakhstan N 10894-Ж, issued 30.04.2010

Periodicity: 6 times a year

Circulation: 500 copies

Editorial address: 28, Shevchenko str., of. 219, 220, Almaty, 050010, tel. 272-13-19, 272-13-18, www:nauka-nanrk.kz / social-human.kz

(C) National Academy of Sciences of the Republic of Kazakhstan, 2018

Address of printing house: ST "Aruna", 75, Muratbayev str, Almaty 
N E W S

OF THE NATIONAL ACADEMY OF SCIENCES OF THE REPUBLIC OF KAZAKHSTAN

SERIES OF SOCIAL AND HUMAN SCIENCES

ISSN 2224-5294

https://doi.org/10.32014/2018.2224-5294.9

Volume 5, Number 321 (2018), 53 - 56

\author{
A.A. Nurpeisova ${ }^{1}$, I.Yu. Rey $^{2}$, D.T. Bizhanov ${ }^{3}$, D.A.Tleuzhanova ${ }^{4}$ \\ ${ }^{1,4}$ Kazakh Agrotechnical University. S.Seifullin; \\ ${ }^{2}$ President, Tour Operator Company "Sayat" ; \\ ${ }^{3}$ JSC "Financial Academy" \\ $\underline{\text { nauryzbaeva_a@mail.ru }}, \underline{\text { sayat01@mail.ru, dokphd.unikum@mail.ru, tda_06@mail.ru }}$
}

\title{
MAIN ELEMENTS OF MANAGING THE PROCESS OF CREATING INNOVATION PRODUCTION
}

\begin{abstract}
The authors of the article consider today the most significant factor related to the success of the company, are the creation of innovations related to the formation of scientific and technological progress. However, innovations in improving the product are least affected in practice and have little effect on the development of the enterprise. Fundamentally significant for the organization of the innovation process is the material and technical base of scientific and design developments. The basic elements of creation of innovative products are revealed, rational management and management of innovative processes is represented, which depends on optimization of expenses for creation of innovations, from terms of realization of given production, and also market opportunities. According to the authors, effective management of innovation processes should include the integration of all elements of the system of science and technology-production-consumption in the process of entrepreneurial activity. At the same time, it is necessary to envisage the creation of a sales system and feedback in the innovation process.
\end{abstract}

Keywords: innovations, competition, efficiency of innovative activity, managerial decisions, economicmathematical model.

\section{INTRODUCTION}

Enterprises introduce innovations to increase the competitiveness of goods and ensure a stable success of the company in the market. In this regard, one of the main areas of strategic management of the enterprise is the management of innovation.

The innovative activity of the company is aimed at scientific and technological progress, namely, the application of its results to improve production efficiency and ensure the competitiveness of the product and the firm as a whole. To achieve this goal, you can detail the objectives of innovation based on the company's strategic programs.

\section{AIN PART}

The main aspects of innovative management are the strategy and technical policy of innovation, as well as specific measures for their implementation.

Innovations include:

- unfamiliar to consumers goods (new products, services);

- an unfamiliar way of creating products or services;

- use of previously unused materials and elements;

- acquisition of new sources of raw materials and energy;

- Innovations in the organization (coverage of new markets, new ways of financing, etc.).

Innovations are any objects or actions that appeared in the organization after scientific research and discoveries or inventions and which are fundamentally different from the previous analog.

Innovations mean a higher technological level, new consumer qualities of a product or service in comparison with previous products. The concept of "innovation" is used with all the innovations of the enterprise, including production, organizational, financial, research and many other areas of activity. In addition, the concept of "innovation" can be attributed to any improvement that provides a reduction in 
costs or creates the conditions for such savings. Innovations are divided into two main groups: technical and organizational.

Technical innovations describe: new products, new technologies or new services. Often the success of the company requires a joint effect, which can be obtained by introducing a new product, new technologies and new services simultaneously. Technical innovations are also classified according to the volume of capital expenditures, from the payback period and from their impact on the formation of a separate company or industry. Then they are divided into basic and applied innovations, innovations related to product improvement, technologies or services and modification innovations.

The most significant impact associated with the success of the company as a whole in the economy are the main innovations associated with the formation of scientific and technological progress. At the same time, innovations in product improvement affect the practice of an industrial enterprise, and in this case the least affected are changes in innovation.

The main objective prerequisites (origins) for the emergence of technical innovations are modern technical capabilities and modern needs, on which two popular models of the innovation process are based. Analysis of the population, taking into account the prerequisites of various innovations in different areas and in different countries, shows that the needs are much more important than the new technical potential in the process of the formation of innovative processes.

To understand the essence and type of the process, it is important which elements of the innovation process take part in it directly as an engine of innovation.

Typical types of such subjects are distinguished:

Innovators, generating new knowledge and creating an intelligent product. Scientific institutions, inventors, small research firms often act as donors of an intellectual product.

- Firms are pioneers of innovation.

- The early majority or early followers, literally "breathing the back of the pioneers". It often happens that this category of subjects removes most of the cream "from the market success of innovation.

- Backward followers, who were late with the timely withdrawal of innovations to the market.

- Simulators acquiring legal rights to manufacture and sale of innovations or carrying out pirated copying from the original product.

For effective implementation of production and economic activities, the main elements must be coordinated in time and space.

In addition to the subjects themselves, other participants in the innovation process are also highlighted, which relate to the near and far environment of the innovative company, among them:

- infrastructure institutions of the state, supporting innovation.

- patent offices and organizations, as well as certification bodies;

- investment funds and financial organizations;

- organization of public and private insurance system;

- institutions of the education system, etc.

The organization of innovation management is a system of measures aimed at the rational use of all its components in a single process of innovation management. From the point of view of the organization, traditionally considered to be the main elements of innovation:

- Defining management objectives.

- Strategy Development.

- Development of a management program.

- Planning of innovation processes.

- Definitions of control technologies (techniques).

- Coordination of work on the implementation of the program.

- Organization of control over the implementation of the innovative program.

- Analysis and evaluation of management effectiveness.

- Correction of innovation processes.

The definition of the objectives of innovation management is largely related to the development of the overall objectives of production and economic activities, including increasing revenues and profits, expanding presence in the market, entering a new market, expanding the range, enhancing the image, etc.

Innovative processes of this or that orientation are carried out in all spheres of social and economic activity of the state within the framework of enterprises and institutions of various forms of ownership. At 
enterprises, innovation processes should cover scientific, informational, design and production activities. It is also impossible not to take into account economic, administrative and socio-cultural activities in the organization of innovative processes.

The most significant for the organization of the innovation process is the material and technical base of scientific and design developments. Rational construction and management of innovation processes depends on optimizing the costs of creating innovations, the timing of their implementation, as well as market opportunities.

Managing the simplest type of innovation process, which is a relatively isolated sequence of actions with the end result and a set of traditional methods as means of implementation, boils down to allocating resources to support this process and creating certain incentives for the participation of all participants in this process.

An effective tool for managing the process of introducing innovations can be the control of the transition from one operation of the innovation process to another. On the other hand, some operations of the process of innovation should be presented as isolated elements, the input of which is the result of previous operations, and the output is products of this stage.

To successfully implement the innovation process, it is necessary to fulfill the mandatory sequential stages: systematize incoming ideas of innovation, formulate ideas for a new product, analyze the economic effectiveness of a new product, create a new product, test a new product on the market and make a decision to launch a new product into production.

At the initial stage of the innovation process, it is necessary to systematize the incoming ideas of innovation. The company's activities, such as, for example, marketing or research, contribute to the accumulation of ideas for further innovations and their systematization. As soon as there is an opportunity or need for innovation, the cycle of innovations begins.

At the first stage of the innovation cycle:

- collect information that covers technological changes in the market, innovations received from $\mathrm{R}$ $\& \mathrm{D}$ departments and marketing services in production departments;

- to study and analyze wishes, demands and complaints that come from consumers in the sales office of the enterprise, as well as from resellers and buyers;

- collect information on the company's permissible potential in areas related to the development and development of new products;

- identify the types of risks, the levels of their impact on the expected output of production and the introduction of innovations;

- to collect and analyze information on target markets and possible options for their development, relevant to innovation.

CONCLUSION

The success of innovation is largely determined by the degree of unimpeded passage of the logical chain of operations. This can be achieved by coordinating adjacent blocks during the transition from one operation to another. For this it does not matter to stimulate the organizations responsible for the respective operations.

Thus, effective management of innovation processes involves the integration of all elements of the system of science and technology-production-consumption in the process of entrepreneurial activity, which should provide for the creation of an extensive system of sales and services to stimulate scientific research and improve inventive activity, linking a new type of communication - communication in the innovation process.

\section{REFERENCES}

[1] Andrizhievsky AA Energy saving and energy management: a textbook / AA Andrizhievsky, VI Volodin. - 2 nd ed., Rev. - Minsk: Higher School, 2005. - 294 p.

[2] Knyaginin V.N. Center for Strategic Studies North-West. Scenarios for the development of the Russian economy. URL: http://ikien.ru/data/Zamena/Prezent_En_B/Knyaginin.pdf

[3] World energy outlook / World energy agency.

URL:

http://www.worldenergyoutlook.org/media/weowebsite/2009/WEO2009.pdf

[4] Unconventional sources of energy. - Moscow: Nauka, 2004.

[5] Vasileva E.V. Modeling of investment of technological innovations in the agroindustrial complex on the basis of competition and integration // - 2014. - No. 10. - P. 109-110.

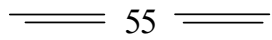


[6] Golub A., Chebotarev A. A model for the effectiveness of innovation financing // Issues of Economics. - 2016. - No. 3. P. 104-107.

[7] Zakharchenko V.I. Innovations: motivation, modeling, efficiency. - Nizhny Novgorod: Scrabble, 2016. - 218 p.

[8] Ketov M.L., Ketov A.M., Shultz M.M. Programming of numerical methods. - Moscow: Grani, 2015. - 612 p.

[9] Savchuk A.V. Innovations in industrial production: classification and interaction // Problems of economic development: regional aspect: Sat. sci. tr. - Samara: SamGU, 2012. - P. 716-720.

[10] Sakhal D. Technical progress: concepts, models, estimates. - Moscow: UNITY-DANA, 2014. - 307 p.

\author{
А.А. Нурпеисова ${ }^{1}$, И.Ю. Рей ${ }^{2}$, Д.Т. Бижанов ${ }^{3}$, Д.А. Тлеужанова ${ }^{4}$ \\ ${ }^{1,4}$ Казахский агротехнический университет им. С.Сейфуллина; \\ ${ }^{2}$ Президент, Туроператорская фирма «Саят»; ${ }^{3} \mathrm{AO}$ «Финансовая академия»
}

\title{
ОСНОВНЫЕ ЭЛЕМЕНТЫ УПРАВЛЕНИЯ ПРОЦЕССОМ СОЗДАНИЯ ИННОВАЦИОННОЙ ПРОДУКЦИИ
}

Аннотация. Авторы статьи считают на сегодняшний день наиболее значительным фактором, связанным с успехом компании, являются создание инноваций, связанные с формированием научно-технического прогресса. Однако, инновации в улучшении продукта наименее затронуты на практике и слабо влияют на развитие предприятия. Фундаментально значительным для организации инновационного процесса является материальнотехническая база научных и проектных разработок. Раскрыты основные элементы создания инновационной продукции, представлено рациональное построение и управление инновационными процессами, которое зависит от оптимизации затрат на создание инноваций, от сроков реализации данной продукции, а также рыночных возможностей. По мнению авторов, эффективное управление инновационными процессами должно включать в себя объединение всех элементов системы науки и технологии-производства-потребления в процессе предпринимательской деятельности. При этом необходимо предусмотреть создание системы продаж и обратную связь в инновационном процессе.

Ключевые слова: инновации, конкуренция, разработка, управленческие решения, экономикоматематическая модель.

\author{
А.А. Нурпеисова ${ }^{1}$, И.Ю. Рей ${ }^{2}$, Д.Т. Бижанов ${ }^{3}$, Д.А.Тлеужанова ${ }^{4}$ \\ ${ }^{1,4}$ Қазақ агротехникалық университеті. С.Сейфуллин; \\ ${ }^{2}$ Президент, «Саят» туроператоры; ${ }^{3}$ «Қаржы академиясы» АҚ
}

\section{ИННОВАЦИЯЛЫҚ ӨНДІРІСДІ ЖАСАУДЫН ПРОЦЕСІН БАҚЫЛАУЫНЫН НЕГІЗГІ ЭЛЕМЕНТТЕРІ}

\footnotetext{
Аннотация. Мақаланың авторлары бүгінгі күні компанияның жетістіктерімен байланысты ең маңызды фактор - ғылыми және технологиялық прогрестің қалыптасуымен байланысты инновацияларды құру болып табылады. Дегенмен, өнімді жетілдірудегі инновациялар практикада аз әсер етеді және кәсіпорынның дамуына аз әсер етеді. Инновациялық процесті ұйымдастыру үшін негізінен маңызды ғылыми және жобалық әзірлемелердің материалдық-техникалық базасы болып табылады. Инновациялық өнімді құрудың негізгі элементтері анықталды, инновациялық процестерді ұтымды басқару және басқару ұсынылды, бұл инновацияларды құру шығындарын оңтайландыруға, осы өндірісті жүзеге асыру шарттарынан, сондай-ақ нарықтық мүмкіндіктерден тұрады. Авторлардың пікірінше, инновациялық процестерді тиімді басқару кәсіпкерлік қызмет барысында ғылым мен техника-өндіріс-тұтыну жүйесінің барлық элементтерін біріктіруді қамтуы тиіс. Сонымен қатар, инновациялық үдерісте сатылым жүйесін құру және кері байланысты құру көзделген.

Түйін сөздер: инновациялар, бәсекелестік, инновациялық қызметтің тиімділігі, басқару шешімдері, экономикалық және математикалық модель.

Information about author:

Nurpeisova A.A. - Kazakh Agrotechnical University. S.Seifullin; https://orcid.org/0000-0001-8949-8359;

Rey I.Yu. - President, Tour Operator Company "Sayat" ; https://orcid.org/0000-0002-7051-8126;

Bizhanov D.T. - JSC "Financial Academy", https://orcid.org/0000-0002-5702-0868;

Tleuzhanova D.A. - Kazakh Agrotechnical University. S.Seifullin; https://orcid.org/0000-0003-2302-1595
} 


\section{МАЗМҰНЫ}

Алтыбаева С.М., Савындыков Е.С. Көркем мәтін құрылымындағы мифопоэтикалық модельдеу және мәдени код...... 5 Сембиева Л.М., Мажитов Д.М., Карпиикая М.Е., Хамитова Д.М. Экономиканы жаңғырту жағдайындағы ЕАЭО елдерінің монетарлық жүесінін өзгеруі .....

Құлсариева А.Т., Султанова М.Э., Шайгозова Ж.Н. Фольклор және сәйкестілік: Қазақстанның қазіргі заманғы

мәдениетіндегі тарих, жады және аңыз шығармашылығы ........................................................................................... 19

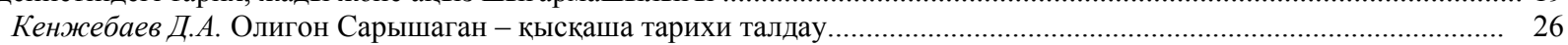

АбдулинаГ.А., БазарбаевА.Г. Ұйымдардағы адам ресурстарын басқарудың заманауи тұжырымдамалары................ 33

Авыбаев А.Н., Адибаева А.К. Геноцид туралы БҰҰ Конвенциясының қатысушы мемлекеттердің қылмыстық

заңнамаларындағы имплементациялық тетіктері: жалпы салыстырмалы талдау............................................................ 39

Ахметжанов Б., Тәжібекова К.Б., Шаметова А.А. Қазақстан көлік өнеркәсіптің дамуын талдау............................. 44

Аюпова 3.К., Құсайынов Д.Ө. Тәуелсіздік жағдайындағы қазақстан республикасының конституциялық-құқықтық

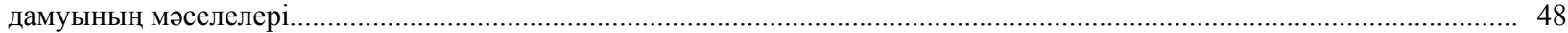

Нурпеисова А.А., Рей И.Ю., Бижанов Д.Т., Тлеужанова Д.А. Инновациялық өндірісді жасаудың процесін

бақылауының негізгі элементтері

Гиздатов Г.Г. Қазақстандық дискурсының құрылымы психолингвистиякалық зерттеу .

Ищанова Р.К. Мемлекеттік шығындарды басқару - мемлекеттің қаржылық тұрақтылығын қамтамасыз ету.............. 64

Мадышева А.М. Бикенова А.С., Елеусиз Л.Т. Білім саласындағы туристік қызметтер............................................. 68

Ескалиева А. Ж., Баймуханова М.Т., Ахмурзина Д.О. Әлеуметтік сала адам капиталының сапасын қолдаудың

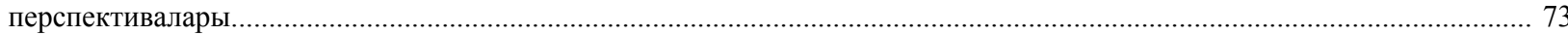

Мархаева Б.А., Козбахова Д.Л. Жауапкершілік орталық және трансферттік баға белгілеу............................................ 79

Сабирова Р.К., Утепкалиева К.М., Кабаков С.Б. Қазақстандағы ауыл шаруашылығы экономикасының

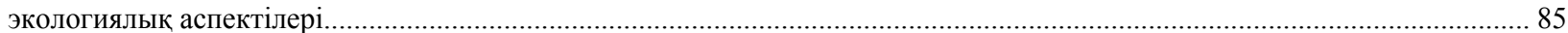

Тлесова Э., Хойч А., Кураш Н. Қазақстан республикасының ғылыми инновациялық потенциясы және оның

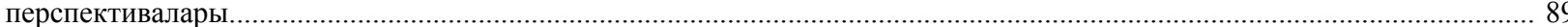

Хамитхан Н. Қазақстандағы банктік қызметтердің сапасын жақсарту жағдайында банкаралык басекелестік............ 95

Шалдарбеков Қ.Б., Муханова Г.С., Нурмухамбетова 3.С. Аймақтарды дамыту бағдарламаларын жүзеге асырудағы жобалық басқаруды қолданудың шетелдік тәжірибесі

КаратаеваА.М., Бердиярова Ж.С. Мемлекеттік қызметшінің әдептік мәдениеті және құқықтық мәдениеті

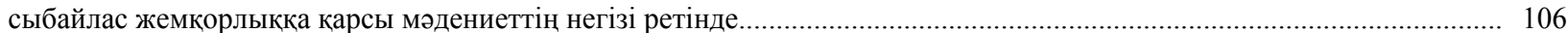

Алдабергенова А.А. Абсурд әдебиетін аударудың лингвомәдени аспектілері ................................................... 113

Стукач В. Ф., Байдалинова А. С., Сандыбаева Б. А. Қазақстанның қаржылық қауіпсіздігі......................................... 119

Баймаханова Д.М., Оспанова Д.А. Конституциялық-құқықтық сана - конституционализмнің маңызды

компоненті ретінде және оның адам құқықтары мәселелерін шешудегі рөлі................................................................. 126

Имангожина 3.А. Сланцевая революция: глобальный тренд на мировом энергетическом рынке............................. 137

Ракаева А.Н., Жуматаева Б.А., Успамбаева М.К., Доскалиева Б.Б. Экологиялық есеп қазақстандағы кәсіпорын экономикасының даму кезеңі ретінде

Нуржанова Г.И. Экономиканың аграрлық секторындағы еңбек әлеуетіне демографиялық фактордың әсері............ 147

Оспанова Д.А., Баймаханова Д.М. Қазақстан Республикасының кибер кеңістігін дамыту жағдайында мемлекеттік қызметтерді цифрландыруда әкімшілік-құқықтық қамтамасыз ету ................................................................................... 152

Pblсnекова М.О., Тлесова Э.Б., Хаитбаева Ф.К. Қазақстандағы тұрғын үй-коммуналдық шаруашылық қызметін

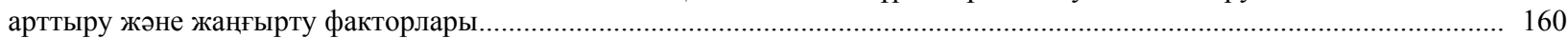

Султанова Г. Т. Аграрлық сектордың экспорттық әлеуетін дамытуға бағытталған үрдістер мен басымдықтар........ 166 


\section{СОДЕРЖАНИЕ}

Алтыбаева С.М., Сагындыков Е.С. Культурный код и мифопоэтическое моделирование в структуре художественного текста

Сембиева Л.М., Мажитов Д.М., Карпиикая М.Е., Хамитова Д.М. Трансформация монетарной системы стран

ЕАЭС в условиях модернизации экономики

Кулсариева А.Т., Султанова М.Э., Шайгозова Ж.Н. Фольклор и идентичность: история, память и мифотворчество

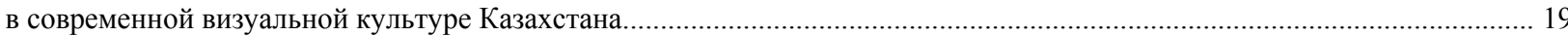

Кенжебаев Д.А. Полигон Сарышаган - краткий исторический анализ................................................................ 26

Абдулина Г.А., БазарбаевА.Г. Современные концепции управления человеческми ресурсами в организациях............ 33

Агыбаев А.Н., Адибаева А.К. Имплементационные механизмы Конвенции ООН о геноциде в уголовных

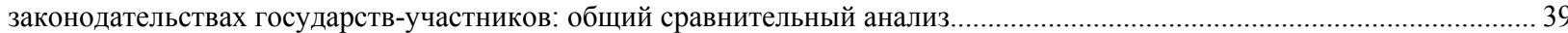

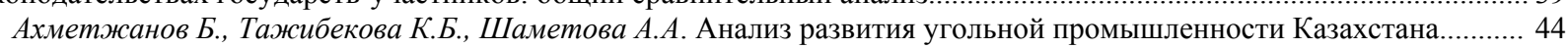

Аюпова 3.К., Кусаинов Д.У.Проблемы конституционно-правового развития республики Казахстан в условиях суверенитета ......

Нурпеисова А.А., Рей И.Ю., Бижанов Д.Т., Тлеужанова Д.А. Основные элементы управления процессом создания инновационной продукции ....

Гиздатов Г.Г. Психолингвистическое исследование концептов казахстанского дискурса......

Ищанова Р.К. Управление государственными расходами - как обеспечение финансовой устойчивости государства. 64

Мадышева А.М. Бикенова А.С., Елеусиз Л.Т. Туристские услуги в сфере образования................................................. 68

Ескалиева А. Ж., Баймуханова М.Т., Ахмурзина Д.О. Перспективы усиления качества человеческого капитала

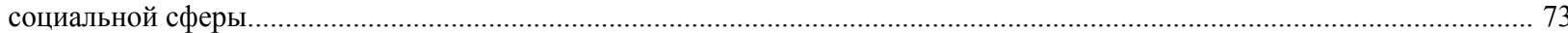

Мархаева Б.А., Козбахова Д.Л. Центр ответственности и трансфертное ценообразование....................................... 79

Сабирова Р.К., Утепкалиева К.М., Кабаков С.Б. Экологические аспекты экономики сельского хозяйства

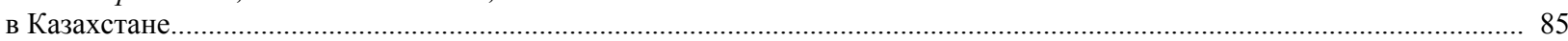

Тлесова Э., Хойч А., Кураш Н. Научно-инновационный потенциал республики Казкастан и его перспективы............ 89

Хамитхан Н. Межбанковская конкуренция в условиях повышения качества банковских услуг в Казахстане..............95

Шалдарбеков К.Б., Муханова Г.С., Нурмухамбетова З.С. Зарубежный опыт применения проектного управления

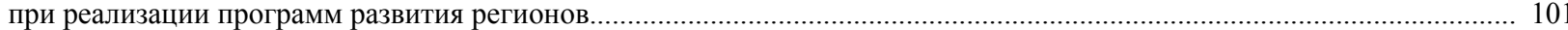

Каратаева А.М., Бердиярова Ж.С. Этическая культура и правовая культура государственных служащих

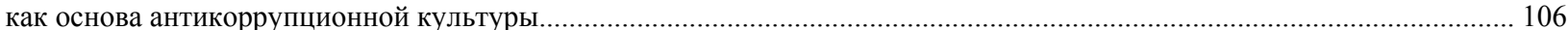

Алдабергенова А.А. Лингвокультурологические аспекты перевода литературы абсурда........................................... 113

Стукач В. Ф., Байдалинова А. С., Сандыбаева Б. А. Казахстанская финансовая безопасность................................... 119

Баймаханова Д.М., Оспанова Д.А. Конституционно-правовое сознание как важный компонент конституционализма

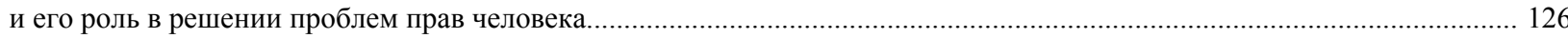

Имангожина 3.А. Сланцевая революция: глобальный тренд на мировом энергетическом рынке............................ 137

Ракаева А.Н., Жуматаева Б.А., Успамбаева М.К., Доскалиева Б.Б. Экологический учет как ступень развития

экономики предприятия в Казахстане............................................................................................

Нуржанова Г.И. Влияние демографического фактора на трудовой потенциал аграрного сектора экономики............ 147

Оспанова Д.А., Баймаханова Д.М. Административно-правовое обеспечение цифровизации государственных услуг в условиях развития кибер пронстранства республики Казахстан......

Рыспекова М.О., Тлесова Э.Б., Хаитбаева Ф.К. Факторы инновационной модернизации и совершенствования деятельности жилищно-коммунального хозяйства в Казахстане

Султанова Г. Т. Тенденции и приоритеты развития экспортного потенциала аграрного сектора... 


\section{CONTENTS}

Altybayeva S.M., Sagyndykov E.S. Cultural code and myth poetic modeling in the structure of the artistic text..................... 5 Sembiyeva L.M., Mazhitov D.M., Karpitskaya M.E., Khamitova D.M. Transformation of the monetary system of the eurasian economic UNION countries in the conditions of modernization of the economy......

Kulsarieva A.T., Sultanova M.E., Shaigozova Zh.N. Folklore and identity: history, memory and myth-making in the modern

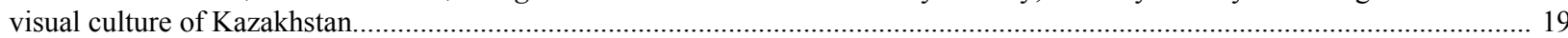

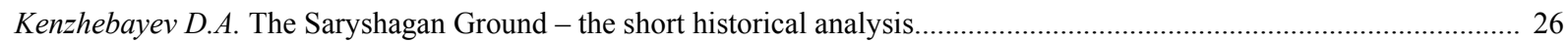

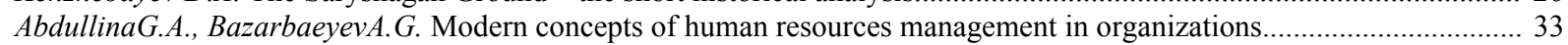

Agybayev A.N., Adibayeva A.K. Implementing mechanisms of the UN Convention on genocide in the criminal legislation

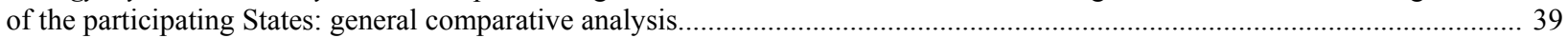

Akhmetzhanov B., Tazhibekova K.B, Shametova A.A. Analysis of development of the coal industry of Kazakhstan.............. 44 Ayupova Z.K., Kussainov D.U. Problems of constitutional and legal development of the republic of kazakhstan in the conditions of sovereignty......

Nurpeisova A.A., Rey I.Yu., Bizhanov D.T., Tleuzhanova D.A. Main elements of managing the process of creating innovation production.

Gizdatov G.G. Psycholinguistic study of the concepts of Kazakhstar

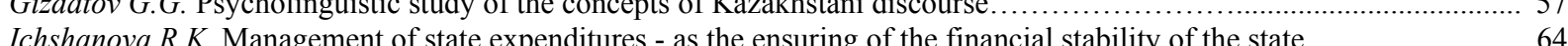

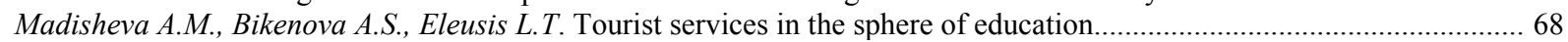

Eskalieva A. Zh., Baymukhanova M.T., Ahmurzina D.O. Perspectives of strengthening the quality of the human capital

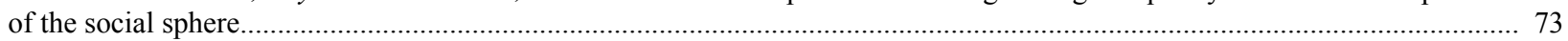

Markhayeva B.A., Kozbakhova D.L. A responsibility center and transfer pricing ................................................. 79

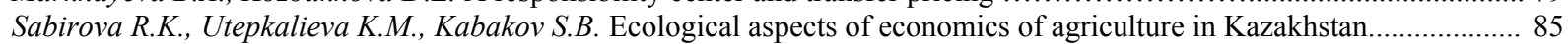

Tlessova E., Khoich A., Kurash N. Scientific innovation potential of the republic of Kazkahstan and its perspectives........ 89

Hamitkhan $N$. Interbank competition in conditions of improving the quality of banking services in Kazakhstan.................. 95

Shaldarbekov K., Mukhanova G., Nurmukhambetova Z. International practices in project management in implementing

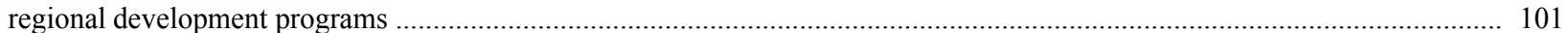

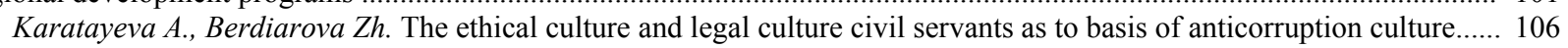

Aldabergenova A.A. Linguocultural aspects of translation of absurd literature.............................................................. 113

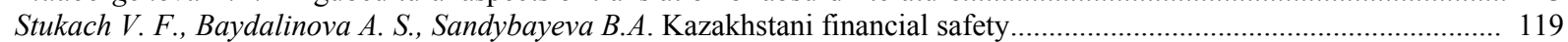

Baimakhanova D.M., Ospanova D.A. Constitutional and legal consciousness as an important component of constitutionalism

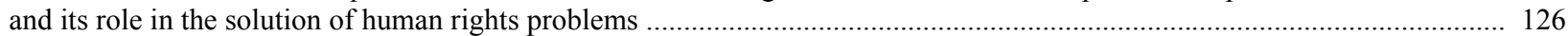

Imangozhina Z.A. Shale gas revolution: global trend in the world energy market..................................................... 137

Rakaeva A.N., Zhumataeva B.A., Uspanbayeva M.K., B.B.Doskalieva. Level of ecological report development in the economic of Kazakhstan's companies.

Nurzhanova G.I. Impact of demographic factors on labor potential of economy's agricultural sector

Ospanova D.A., Baimakhanova D.M. Administrative and legal support of digitalization of public services in the context of the development of cyber space in the republic of Kazakhstan....

Ryspekova M.O., Tlessova E.B., Khaitbayeva F. Factors of innovative modernization and improvement of activity

of housing and communal services in Kazakhstan.

Sultanova G. T. Trends and priorities for the development of export potential of the agrarian sector. 


\title{
PUBLICATION ETHICS AND PUBLICATION MALPRACTICE IN THE JOURNALS OF THE NATIONAL ACADEMY OF SCIENCES OF THE REPUBLIC OF KAZAKHSTAN
}

For information on Ethics in publishing and Ethical guidelines for journal publication see http://www.elsevier.com/publishingethics and http://www.elsevier.com/journal-authors/ethics.

Submission of an article to the National Academy of Sciences of the Republic of Kazakhstan implies that the work described has not been published previously (except in the form of an abstract or as part of a published lecture or academic thesis or as an electronic preprint, see http://www.elsevier.com/postingpolicy), that it is not under consideration for publication elsewhere, that its publication is approved by all authors and tacitly or explicitly by the responsible authorities where the work was carried out, and that, if accepted, it will not be published elsewhere in the same form, in English or in any other language, including electronically without the written consent of the copyrightholder. In particular, translations into English of papers already published in another language are not accepted.

No other forms of scientific misconduct are allowed, such as plagiarism, falsification, fraudulent data, incorrect interpretation of other works, incorrect citations, etc. The National Academy of Sciences of the Republic of Kazakhstan follows the Code of Conduct of the Committee on Publication Ethics (COPE), and follows the COPE Flowcharts for Resolving Cases of Suspected Misconduct (http://publicationethics.org/files/u2/New Code.pdf). To verify originality, your article may be checked by the originality detection service Cross Check http://www.elsevier.com/editors/plagdetect.

The authors are obliged to participate in peer review process and be ready to provide corrections, clarifications, retractions and apologies when needed. All authors of a paper should have significantly contributed to the research.

The reviewers should provide objective judgments and should point out relevant published works which are not yet cited. Reviewed articles should be treated confidentially. The reviewers will be chosen in such a way that there is no conflict of interests with respect to the research, the authors and/or the research funders.

The editors have complete responsibility and authority to reject or accept a paper, and they will only accept a paper when reasonably certain. They will preserve anonymity of reviewers and promote publication of corrections, clarifications, retractions and apologies when needed. The acceptance of a paper automatically implies the copyright transfer to the National Academy of sciences of the Republic of Kazakhstan.

The Editorial Board of the National Academy of sciences of the Republic of Kazakhstan will monitor and safeguard publishing ethics.

Правила оформления статьи для публикации в журнале смотреть на сайте:

$$
\begin{gathered}
\text { www:nauka-nanrk.kz } \\
\text { social-human.kz }
\end{gathered}
$$

\author{
Редакторы М.С. Ахметова, Т.А. Апендиев, Д.С. Аленов \\ Верстка на компьютере А.М. Кульгинбаевой \\ Подписано в печать 10.10.2018 \\ Формат 60x881/8. Бумага офсетная. Печать - ризограф. \\ 11,6 п.л. Тираж 500. Заказ 5.
}

